\title{
Perceived Social Support in Recreational Activity Participation: A Study on Students
}

\author{
Huseyin Gumus ${ }^{1}$, Ayse Asli Honca ${ }^{2} \&$ Turan Cetinkaya ${ }^{3}$ \\ ${ }^{1}$ Physical Education and Sports School, Mersin University, Mersin, Turkey \\ ${ }^{2}$ Physical Education and Sports School, Kastamonu University, Kastamonu, Turkey \\ ${ }^{3}$ Physical Education and Sports School, Ahi Evran University, Kirsehir, Turkey \\ Correspondence: Huseyin Gumus, Mersin University, Physical Education and Sports School, Mersin University \\ Beden Egitimi ve Spor Yuksekokulu, Mersin Universitesi Ciftlikkoy Kampusu Beden Egitimi ve Spor \\ Yuksekokulu 33343 Yenisehir / MERSIN, Turkey. E-mail: huseyinn.gumuss@ gmail.com
}

Received: January 22, 2019

Accepted: February 18, 2019 Online Published: February 19, 2019

doi:10.5539/hes.v9n1p151

URL: https://doi.org/10.5539/hes.v9n1p151

\begin{abstract}
The purpose of this study is to examine university students' perceived social support level in recreational activity participation. 536 students who were selected from 3 different universities using convenience sampling participated in the study voluntarily. As data collection form; Perceived Social Support Scale (PSSS-R) and Preference Factors of Recreation Areas (PFRA) scale were used. For the analyses of the data; descriptive statistics, Independent Samples T Test used for two groups depending on the number of the variables and One Way ANOVA used for groups more than two were used. In order to find out which group demonstrated the difference found as a result of variance analyses, Tukey test -one of the multiple comparison tests- was used. In terms of recreational activity participation, the most effective factor in students' average scores of perceived social support scale was peer support $(2.690 \pm 0.372)$ while the least effective factor was teacher support $(2.033 \pm 0.535)$. Total average score was found to be $2.441 \pm 0.274$. The most effective factor in students' average scores of Recreation Area Preference Agents Scale was sporting diversity (4.448 \pm 0.776$)$ and staff $(4.128 \pm 0.681)$ and these factors were followed by physical facilities $(3.736 \pm 0.562)$, location $(3.185 \pm 0.647)$ and activity diversity (3.074 \pm 0.586 ); respectively. Besides, there were significant differences in perceived social support levels of the study group in terms of gender and accommodation variables. It was concluded that the highest support for students' recreational activity participation came from their peers while the lowest support was obtained from teachers. It may be argued that students staying at public dormitories used recreational areas built by municipalities more than other students. It was identified that criterion that all the student groups put the biggest emphasis on while preferring recreation areas was sporting diversity offered by the recreation areas.
\end{abstract}

Keywords: social support, recreation, activity, leisure, student

\section{Introduction}

Humans as social beings develop their personality by continuously interacting with the environment by their very nature and thus lead their lives by integrating themselves into the environment (Terzi, 2008). Humans, with a need to be loved and cared by their environment, expect to meet this need-primarily-from their families and peers. On the other hand; humans -also wanting to be supported by the social groups that they belong to- support this need with social relations they form (Oksuz et al., 2011). Social support as a term refers to providing individuals with knowledge, recommendations, financial help that contribute to their feelings and behaviors positively or supporting them in their relations to the environment and others (Gottlieb, 1983). Knowing perceived social support level in individuals may be helpful in different ways. For Caplan, (1974) knowing social support systems assist individuals to activate their psychobiological sources, to meet their wishes and to access to financial and monetary resource by making them skilled. Also, social support systems help individuals by guiding them and providing them with knowledge. Social support systems help individuals in three different manners. First, social support systems eliminate or reduce some elements that affect their experiences negatively. Second, social support systems enhance individuals' endurance strength in case of negative experiences and improve their health status. Third, social support systems lessen environmental effects of stressors. Studies done for the last 20 years on the role of social support in every area have played a key role in understanding the 
importance of social support (Guler \& Turkmen, 2018; Zhang et al., 2016; Yildirim, 2016; Feeney \& Collins, 2015; Avci \& Yildirim, 2014; Peker \& Eroglu, 2015; Gungor et al., 2018).

When humans as social beings face with a negative and unwanted situation, support systems felt nearby contribute them positively in coping with struggles. Humans always want to be included in social webs because they are born, grow up and develop in society. These social webs influence well-being of individuals (Karatas, 2012). Another factor that influences people's well-being is recreational activities. Recreation is defined as activities chosen for being engaged after spending the necessary time for work and physiological needs and is a multi-faceted term that includes social, physical and mental dynamics (Broadhurst, 2001). Recreation is any voluntarily performed activity in order to gain some social and emotional behaviors in person or in groups during their free time. This term is a feeling that is formed for satisfaction and well-being (Kilbas, 2010). Particularly, increased free time thanks to -particularly- technological advancements of the 21 st century has resulted in serious demand for recreational activities (Kozak, Aydin C \& Aydin Ç, 2017). Recreational activities, in which individuals participate so that they can get rid of stress, regain psychological and physical health and have fun (Kocyigit \& Yildiz, 2014) play a crucial role in developing social relations, too (Broadhurst, 2001; Buchecker \& Degenhardt, 2015). However, the studies done indicate that "Family" and "Peer" subdimensions are significant barriers to recreational activity participation (Soyer et al., 2017; Sarol, 2017; Gurbuz \& Henderson, 2014; Gumus, Ozgul \& Karakilic, 2017; Aydin, Kahraman \& Hiçdurmaz, 2017; Mumcu \& Ozgul, 2018).

There are numerous studies that emphasize positive correlation of social support with physiological and psychological health (Iskender \& Tas, 2018; Dokmen, 2017; Turgut \& Capan, 2017; Cavus \& Pekkan, 2017; Uygur, 2018) whereas there are almost no studies on recreational activity participation and social support. Therefore, this study focused on examining university students' perceived social support level in recreational activity participation.

\section{Materials and Methods}

This section includes the group, the data collection tool, analyses, methods, and techniques related to the data.

\subsection{Participants}

A total of 622 students -234 female students and 302 male students- who studied at 3 different public universities in Turkiye (Mersin University, Kirsehir Ahi Evran University, Kastamonu University), were aged between 19 and 30 years and were recruited using convenience sampling participated in the study. 86 forms filled in wrongly or incompletely were excluded from the study. Eventually, the study sample consisted of 536 students.

\subsection{Collection of Data}

"Information Request Form", "Perceived Social Support Scale" and "Recreation Areas Preference Agencies Scale" were administered to the students who studied at Mersin University, Kirsehir Ahi Evran University and Kastamonu University during the 2017-2018 academic year with voluntariness principle. Participants were informed of the data collection tools before the administration of the scales and they have explained the importance of responding questions candidly. Administration of the tools took averagely 8 minutes.

\subsection{Data Collection Tools}

In collecting data; an Information Request Form designed by the researchers in order to get information on participants' age, gender, income level and accommodation status, "Perceived Social Support Scale" and "Recreation Area Preference Agents Scale" were employed.

Perceived Social Support Scale (PSSS): PSSS, designed by Yildirim (1997) for the Turkish society PSSS, was revised in 2004. PSSS-R includes three subdimensions of Family Support (FS), Peer Support (PS) and Teacher Support (TS) with 50 items. 47 items of the scale are direct worded while 3 items are reverse worded. Therefore, three items are reverse scored and total scores are calculated. PSSS supports a structure of 46 items and 3 factors in this study and its reliability coefficients are 0.92 for FS, 0.78 for PS, 0.93 for TS and 0.93 for total scale. After varimax rotation of three factors found in the principal components factor analysis, items account for $61.109 \%$ of the scale.

Preference Factors of Recreation Areas (PFRA): PFRA, developed by Gumus and Ozgul (2017), is a 5-point Likert scale consisted of 24 items with 5 subdimensions- Sporting Diversity (SD), Staff (S), Location (L), Physical Facilities (PF) and Activity (A) (1: Not important at all, 5: very important) [30]. There are no reverse scored items. Internal consistency coefficients are 0.84 for Sporting Diversity, 0.80 for Staff, 0.70 for Location, 0.82 for Physical facilities and 0.81 for Activity. 


\subsection{Analysis of Data}

For the analyses of the data; descriptive statistics (percentages, frequencies etc.), explanatory factor analysis, Independent Samples T-Test used for two groups depending on the number of the variables and One Way ANOVA used for groups more than two were used. In order to find out which group demonstrated the difference obtained as a result of variance analyses, Tukey test -one of the multiple comparison tests- was used.

\section{Results}

In this section, findings of the variables of the study are included.

Table 1. PFRA and PSSS average scores

\begin{tabular}{llccl}
\hline & Subdimension & $\mathrm{N}$ & $\overline{\boldsymbol{x}}$ & $\mathrm{sd}$ \\
\hline PFRA & Sporting Diversity & 536 & 4.24 & .766 \\
& Staff & 536 & 4.24 & .680 \\
& Location & 536 & 4.15 & .699 \\
& Physical Facilities & 536 & 4.17 & .562 \\
& Activity & 536 & 4.07 & .708 \\
\hline PSSS & Family Support & 536 & 2.60 & .372 \\
& Peer Support & 536 & 2.69 & .316 \\
& Teacher Support & 536 & 2.03 & .535 \\
& Total Perceived Social Support (PSS) & 536 & 2.44 & .274 \\
\hline
\end{tabular}

Table 2. ANOVA results of PFRA according to Perceived Social Support Level

\begin{tabular}{lllllll}
\hline Subdimension & PSS Level & $\mathrm{N}$ & $\overline{\boldsymbol{x}}$ & $\mathrm{sd}$ & $\mathrm{F}$ & $\mathrm{p}$ \\
\hline \multirow{3}{*}{ Sporting Diversity } & Low & 52 & 4.24 & .96 & & \\
& Moderate & 279 & 4.18 & .79 & 1.594 & .204 \\
& High & 205 & 4.31 & .67 & & \\
\hline \multirow{3}{*}{ Staff } & Low & 52 & 4.25 & .71 & & \\
& Moderate & 279 & 4.18 & .69 & 2.668 & .070 \\
& High & 205 & 4.33 & .64 & & \\
\hline \multirow{3}{*}{ Location } & Low & 52 & 4.26 & .51 & & \\
& Moderate & 279 & 4.19 & .68 & 4.304 & $.014^{*}$ \\
& High & 205 & 4.11 & .56 & & \\
\hline \multirow{3}{*}{ Physical Facilities } & Low & 52 & 4.26 & .67 & & \\
& Moderate & 279 & 4.10 & .74 & 1.95 & .143 \\
& High & 205 & 4.20 & .63 & & \\
\hline \multirow{3}{*}{ Activity } & Low & 52 & 4.17 & .77 & & \\
& Moderate & 279 & 4.06 & .72 & .540 & .583 \\
& High & 205 & 4.06 & .67 & & \\
\hline
\end{tabular}

When participants' average scores of recreation areas preference agencies scale was investigated in terms of perceived social support level; it was noted that location subdimension produced a significant difference in individuals' perceived social support level. Individuals whose PSS (perceived social support) level was lower attached more importance to location subdimension in comparison with those individuals with moderate and high perceived social support level (Table 2). 
Table 3. T-test results of PFRA and PSSS average scores in terms of gender

\begin{tabular}{|c|c|c|c|c|c|c|c|}
\hline & Subdimension & Gender & $\mathrm{N}$ & $\overline{\boldsymbol{x}}$ & sd & $\mathrm{t}$ & $\mathrm{p}$ \\
\hline \multirow{10}{*}{ PFRA } & \multirow[b]{2}{*}{ Sporting Diversity } & Men & 302 & 4.16 & .78 & \multirow{2}{*}{-2.568} & \multirow{2}{*}{$.011^{*}$} \\
\hline & & Women & 234 & 4.33 & .72 & & \\
\hline & \multirow{2}{*}{ Staff } & Men & 302 & 4.16 & .66 & \multirow{2}{*}{-3.087} & \multirow{2}{*}{$.002^{*}$} \\
\hline & & Women & 234 & 4.35 & .69 & & \\
\hline & \multirow{2}{*}{ Location } & Men & 302 & 4.10 & .68 & \multirow{2}{*}{-2.073} & \multirow{2}{*}{$.039^{*}$} \\
\hline & & Women & 234 & 4.23 & .71 & & \\
\hline & \multirow{2}{*}{ Physical Facilities } & Men & 302 & 4.06 & .56 & \multirow{2}{*}{-5.409} & \multirow{2}{*}{$.001^{*}$} \\
\hline & & Women & 234 & 4.32 & .51 & & \\
\hline & \multirow{2}{*}{ Activity } & Men & 302 & 3.99 & .73 & \multirow{2}{*}{-3.315} & \multirow{2}{*}{$.001 *$} \\
\hline & & Women & 234 & 4.19 & .65 & & \\
\hline \multirow{8}{*}{ PSSS } & \multirow{2}{*}{ Family Support } & Men & 302 & 2.56 & .39 & \multirow{2}{*}{-2.745} & \multirow{2}{*}{$.006^{*}$} \\
\hline & & Women & 234 & 2.65 & .33 & & \\
\hline & \multirow{2}{*}{ Peer Support } & Men & 302 & 2.64 & .34 & \multirow{2}{*}{-3.742} & \multirow{2}{*}{$.001 *$} \\
\hline & & Women & 234 & 2.74 & .26 & & \\
\hline & \multirow{2}{*}{ Teacher Support } & Men & 302 & 2.03 & .52 & \multirow{2}{*}{.094} & \multirow{2}{*}{.925} \\
\hline & & Women & 234 & 2.03 & .55 & & \\
\hline & \multirow{2}{*}{ Total Perceived Social Support } & Men & 302 & 2.41 & .28 & \multirow{2}{*}{-2.605} & \multirow{2}{*}{$.009 *$} \\
\hline & & Women & 234 & 2.47 & .25 & & \\
\hline
\end{tabular}

When participants' average scores of recreation area preference agencies scale were examined in terms of gender, it was found that there were significant differences in all subdimensions. It may be argued that in perceived social support levels, gender was the variable that produced significant differences in all the subdimensions except Teacher support.

Table 4. ANOVA results of PFRA and PSSS according to accommodation

\begin{tabular}{|c|c|c|c|c|c|c|c|}
\hline & Subdimension & Accommodation & $\mathrm{N}$ & $\overline{\bar{x}}$ & $\mathrm{Sd}$ & $\mathrm{F}$ & $\mathrm{p}$ \\
\hline & & Dormitory & 161 & 4.38 & .68 & & \\
\hline & Sporting Diversity & Home & 94 & 4.19 & .68 & 3.927 & $.020 *$ \\
\hline & & Family & 281 & 4.17 & .82 & & \\
\hline & & Dormitory & 161 & 4.24 & .72 & & \\
\hline & Staff & Home & 94 & 4.31 & .64 & .685 & .505 \\
\hline & & Family & 281 & 4.22 & .66 & & \\
\hline & & Dormitory & 161 & 4.19 & .69 & & \\
\hline PFRA & Location & Home & 94 & 4.13 & .69 & .289 & .749 \\
\hline & & Family & 281 & 4.14 & .70 & & \\
\hline & & Dormitory & 161 & 4.30 & .54 & & \\
\hline & Physical Facilities & Home & 94 & 4.19 & .50 & 7.236 & $.001 *$ \\
\hline & & Family & 281 & 4.09 & .57 & & \\
\hline & & Dormitory & 161 & 4.12 & .71 & & \\
\hline & Activity & Home & 94 & 4.10 & .66 & .775 & .461 \\
\hline & & Family & 281 & 4.04 & .72 & & \\
\hline & & Dormitory & 161 & 2.64 & .33 & & \\
\hline & Family Support & Home & 94 & 2.58 & .43 & 1.838 & .160 \\
\hline & & Family & 281 & 2.57 & .37 & & \\
\hline & & Dormitory & 161 & 2.71 & .30 & & \\
\hline & Peer Support & Home & 94 & 2.77 & .27 & 6.983 & $.001 *$ \\
\hline & & Family & 281 & 2.64 & .33 & & \\
\hline PSSS & & Dormitory & 161 & 2.06 & .52 & & \\
\hline & Teacher Support & Home & 94 & 1.95 & .58 & 1.202 & .302 \\
\hline & & Family & 281 & 2.04 & .52 & & \\
\hline & & Dormitory & 161 & 2.47 & .25 & & \\
\hline & Total Perceived Social Support & Home & 94 & 2.44 & .26 & 2.071 & .127 \\
\hline & & Family & 281 & 2.42 & .28 & & \\
\hline
\end{tabular}


When participants' average scores of recreation area preference agencies scale were examined in terms of accommodation, it was found that there were significant differences in the subdimensions of sporting diversity and physical facilities. According to the Tukey test performed, the significant difference was created by those students who stayed at dormitories. In perceived social support scale scores, peer support subdimension produced a significant difference. This difference was caused by those individuals who stayed with families.

Table 5. Correlation coefficients between PFRA and PSSS

\begin{tabular}{|c|c|c|c|c|c|c|}
\hline $\mathrm{N}: 536$ & & PSSS & SD & $\mathrm{S}$ & $\mathrm{L}$ & $\mathrm{PF}$ \\
\hline \multirow{2}{*}{ SPORTING DIVERSITY (SD) } & Pearson Correlation & .074 & & & & \\
\hline & Sig. (2-tailed) & .087 & & & & \\
\hline \multirow{2}{*}{ STAFF (S) } & Pearson Correlation & .071 & $.627 * *$ & & & \\
\hline & Sig. (2- tailed) & .101 & .000 & & & \\
\hline \multirow{2}{*}{ LOCATION (L) } & Pearson Correlation & .001 & $.450 * *$ & $.451 * *$ & & \\
\hline & Sig. (2- tailed) & .973 & .000 & .000 & & \\
\hline \multirow{2}{*}{ PHYSICAL FACILITIES (PF) } & Pearson Correlation & .064 & $.543 * *$ & $.593 * *$ & $.471 * *$ & \\
\hline & Sig. (2- tailed) & .138 & .000 & .000 & .000 & \\
\hline ACTIVITY (A) & $\begin{array}{l}\text { Pearson Correlation } \\
\text { Sig. (2- tailed) }\end{array}$ & $\begin{array}{l}-.032 \\
.459\end{array}$ & $\begin{array}{l}.454 * * \\
.000\end{array}$ & $\begin{array}{l}.469 * * \\
.000\end{array}$ & $\begin{array}{l}.321 * * \\
.000\end{array}$ & $\begin{array}{l}.662 * * \\
.000\end{array}$ \\
\hline
\end{tabular}

**Correlation is significant at the 0.01 level (2-tailed).

When Table 5 was looked at, no significant correlation was found between the scores of Recreation Areas Preference Agencies Scale and Perceived Social Support Scale.

\section{Discussion and Conclusions}

In this study, where perceived social support was investigated in relation to recreational activities, it was concluded that participants perceived the highest social support from their peers (Table 1). The studies done emphasize that peer factor is one of the most important factor in recreational activity participation (Mumcu \& Alay Ozgul, 2018; Uzun et al., 2017; Ayhan et al., 2018; Chick et al., 2015; Ayhan et al., 2017). We are of the opinion that in university years during which friendship and peer relations grow more important, social support level that individuals feel is maximized because they feel that they belong to a peer group and enter into close relations with their peers. Actually, the study of Yardimci \& Basbakkal (2009) point out similar results and concur with this study. Peer factor is particularly an important motivation for participating in campus recreation areas and those built by municipalities (Brock et al., 2015; Henchy, 2011). It was found that factors to which study group attached the most importance while preferring recreation areas were "Sporting diversity" and "Staff" subdimensions. Therefore, it may be suggested that recreation areas that provide tools as well as auxiliary staff such as security staff, cleaning staff, sports counselors of different sportive branches play a key role in choosing recreation areas where individuals want to visit. According to Gumus (2016); presence of sports staff, cleaning staff and security staff and presence of sports counselors in a recreation area makes it more desirable than others. Similarly, a recreation area that provides walking trail and bicycle lane, offer facilities for different sports branches makes it possible for more individuals to benefit from it.

According to another finding of the study, when participants' scores of recreation areas preference agencies scale were investigated in terms of perceived social support level, it was seen that individuals' perceived social support level produced a significant difference in location subdimension. It may be suggested that individuals with lower PSS level cared more location subdimension as compared to those with moderate and high perceived social support level (Table 2). According to what this finding indicated, individuals with lower PSS level paid more attention to such factors as recreation areas being closer to their house and city center and being accessible by mass transportation -while choosing recreation areas-. Actually, studies done emphasize that lack of security and social support is a crucial factor in participating in recreation area (Coleman, 1993; Iso-Ahola \& Park, 1996; Twenge et al., 2010).

Another finding of the study results demonstrated that gender created significant differences in all subdimensions while preferring a recreation area (Table 3). It may be argued that in perceived social support levels, gender was the variable that produced significant differences in all the subdimensions but teacher support. This finding emphasizes that gender is an important variable in recreation areas preference. The study of Aradahan \& Yerlisu Lapa (2011) reports that men are more comfortable and active in recreation preference because they are supported by such social institutions as work, family, social responsibilities while women have 
more restricted opportunities in recreational preferences due to the roles that they adopt. The study of Thapa, Confer \& Mendelson (2004) tell that men join more activities in recreation areas than women. Since men's habits to use sportive free time are stronger than women's habits (Iskender et al., 2015), women are more restricted in having opportunities in recreational preferences than men; as a result of which women are bound to take more factors into consideration while choosing recreation areas. Similarly; perceived social support scale demonstrated that women perceived more support as compared to men. In literature, there are studies stating that women perceive more social support as compared to men (Allen \& Stoltenberg, 1995; Antonucci, 1987; Stokes $\&$ Wilson, 1984).

When participants' scores of recreation area preference agencies scale were examined in terms of accommodation, it was found that there were significant differences in the subdimensions of sporting diversity and physical facilities. According to the Tukey test performed, the significant difference was created by those students who stayed at dormitories. According to this finding, students who stay at dormitories attach more importance to physical facilities than other students who stay with their families; upon which the fact that students who stay at dormitories have fewer and restricted physical facilities is effective. Similarly; since times to enter and to exit dormitories are predetermined, students with a limited time prefer those recreation areas that offer more range of sporting diversity. The study of Bedimo-Rung et al. (2005) reports that parks with different physical activity opportunities are preferred by those individuals with the bigger time problem.

\section{Acknowledgment}

This study was presented as an oral presentation at the 16th International Sports Sciences Congress

\section{References}

Allen, S. F., \& Stoltenberg, C. D. (1995). Psychological separation of older adolescents and young adults from their parents: An investigation of gender differences. Journal of Consulting and Development, 73, 542-546. https://doi.org/10.1002/j.1556-6676.1995.tb01791.x

Antonucci, T. C., \& Akiyama, H. (1987). An examination of sex differences in social support among older men and women. Sex Roles, 17(11/12), 737-749. https://doi.org/10.1007/BF00287685

Ardahan, F., \& Lapa, Y. T. (2011). Açık alan rekreasyonu: Bisiklet kullanıcıları ve yürüyüşüülerin doğa sporu yapma nedenleri ve elde ettikleri faydalar. Uluslararası Insan Bilimleri Dergisi, 8(1), 1327-1341.

Avcı, Ö. H., \& Yıldırım, İ. (2014). Ergenlerde şiddet eğilimi, yalnızlık ve sosyal destek. Hacettepe Universitesi Eğitim Fakültesi Dergisi, 29(29-1).

Aydın, A., Kahraman, N., \& Hiçdurmaz, D. (2017). Hemşirelik Öğrencilerinin Algılanan Sosyal Destek ve Psikolojik İyi Olma Düzeylerinin Belirlenmesi. Psikiyatri Hemşireliği Dergisi, 8(1), 40-47.

Ayhan, C., Ekinci, N., Yalçın, I., \& Yiğit, S. (2018). Investigation of Constraints that Occur during Participation in Leisure Activities by High School Students: A Sample of Turkey. Education Sciences, 8(2), 86. https://doi.org/10.3390/educsci8020086

Ayhan, C., Eskiler, E., \& Soyer, F. (2017). Aktif Sporcuların Rekreatif Etkinliklere Katılımlarına Engel Oluşturabilecek Faktörlerin Yaşam Tatmini ve Yaşam Kalitesi Üzerine Etkisi, Erpa Int. Congresses on Education, Hungary, 164-175.

Bedimo-Rung, A. L., Mowen, A. J., \& Cohen, D. A. (2005). The significance of parks to physical activity and public health: a conceptual model. American journal of preventive medicine, 28(2), 159-168. https://doi.org/10.1016/j.amepre.2004.10.024

Broadhurst, R. (2001). Managing Environmets for Leisure and Recreation, GBR: Routledge, London.

Brock, M., Carr, J. W., \& Todd, M. K. (2015). An examination of campus recreation usage, academic performance, and selected health indices of college freshmen. Recreational Sports Journal, 39(1), 27-36. https://doi.org/10.1123/rsj.2014-0061

Buchecker, M., \& Degenhardt, B. (2015). The Effects of Urban Inhabitants' Nearby Outdoor Recreation on Their Well-Being and Their Psychological Resilience. Journal of Outdoor Recreation and Tourism, 10, 55-62. https://doi.org/10.1016/j.jort.2015.06.007

Caplan, G. (1974). Support Seystern and Community Mental Health. New York: Behavioral Publications.

Çavuş, M. F., \& Pekkan, N. Ü. (2017). Algılanan Sosyal Desteğin Sosyal Girişimciliğe Etkisi: Üniversite Öğrencileri Üzerinde Bir Araştırma 1. Business and Economics Research Journal, 8(3), 519.

https://doi.org/10.20409/berj.2017.64 
Chick, G., Hsu, Y. C., Yeh, C. K., \& Hsieh, C. M. (2015). Leisure constraints, leisure satisfaction, life satisfaction, and self-rated health in six cities in Taiwan. Leisure Sciences, 37(3), 232-251. https://doi.org/10.1080/01490400.2014.967897

Coleman, D. (1993). Leisure based social support, leisure dispositions and health. Journal of Leisure research, 25(4), 350-361. https://doi.org/10.1080/00222216.1993.11969933

Dökmen, Z. Y. (2017). Yakınlarına bakım verenlerin ruh sağlıkları ile sosyal destek algıları arasındaki ilişkiler. Ankara Üniversitesi Sosyal Bilimler Dergisi, 3(1).

Feeney, B. C., \& Collins, N. L. (2015). A new look at social support: A theoretical perspective on thriving through relationships. Personality and Social Psychology Review, 19(2), 113-147. https://doi.org/10.1177/1088868314544222

Gottlieb, B. H. (1983). Social support as a focus for integrative research in psychology. American Psychologist, 38(3), 278-287. https://doi.org/10.1037/0003-066X.38.3.278

Guler, H., \& Turkmen, M. (2018). Investigation of the effects of leisure time constraints of the university students in physical education and sport scholls on their leisure time motivation: Bartin university sample. International Journal of Recreation and Sport Science, 2(1), 39-52. Retrieved from http://dergipark.gov.tr/ijrss/issue/41363/490963

Gümüş, H. (2016). Rekreasyonel Alanların Kullanım Etkenlerinin İncelenmesi. Yayınlanmamış doktora tezi, Gazi Üniversitesi Sağlık Bilimleri Enstitüsü, Ankara.

Gümüş, H., \& Özgül, S. A. (2017). Development of scales for barriers to participation and preference factors in the use of recreation area. Journal of Human Sciences, 14(1), 865-882. https://doi.org/10.14687/jhs.v14i1.4448

Gümüş, H., Özgül, S. A., \& Karakılıç, M. (2017) Fiziksel Aktivite İçin Park ve Rekreasyon Alanlarına Gelen Kullanıcıların Mekân Seçimini ve Fiziksel Aktiviteye Katılımını Etkileyen Faktörler. Spormetre, 15(1), 31-38.

Gungor, N., Kurtipek, S., \& Yenel, F. (2018). The needs for cognition and cognitive avoidance: The example of the faculty of sports science. International journal of recreation and sport science, 2, 30-38. Retrieved from http://dergipark.gov.tr/ijrss/issue/41363/468427

Gürbüz, B., \& Henderson K. A. (2014). Leisure Activity Preferences and Constraints: Perspectives from Turkey. World Leisure Journal, 56(4), 300-316. https://doi.org/10.1080/16078055.2014.958195

Henchy, A. (2011). The influence of campus recreation beyond the gym. Recreational Sports Journal, 35(2), 174-181. https://doi.org/10.1123/rsj.35.2.174

İskender, A., Avcı, C., \& Yaylı, A. (2015). Gençlerin serbest zaman değerlendirme aracı olarak rekreatif faaliyetlere katılım düzeylerinin belirlenmesi. Journal of Recreation and Tourism Research, 2(1), 36-42.

İskender, M., \& Taş, İ. (2018). Ergenlerde Savunma Biçimleri ve Sosyal Desteğin Şiddet Eğilimine Etkisi. International Online Journal of Educational Sciences, 10(2).

Iso-Ahola, S. E., \& Park, C. J. (1996). Leisure-related social support and self-determination as buffers of stress-illness relationship. Journal of Leisure Research, 28(3), 169-187. https://doi.org/10.1080/00222216.1996.11949769

Karataş, Z. (2012). Ergenlerin algılanan sosyal destek ve sürekli kaygı̈ düzeylerinin incelenmesi. Mustafa Kemal Üniversitesi Sosyal Bilimler Enstitüsü Dergisi, 9(19), 257-271.

Kılbaş, Ş. (2010). Rekreasyon (Boş Zamanı Değerlendirme), Gazi Kitapevi, 4. Baskı, Ankara.

Koçyiğit, M., \& Yıldız, M. (2014). Yerel Yönetimlerde Rekreasyon Uygulamaları: Konya örneği. International Journal of Science Culture and Sport, 2, 211-223. https://doi.org/10.14486/IJSCS193

Kozak, M. A., Aydin, Ç., \& Aydin, C. (2017). Rekreasyon Faaliyetlerine Katılan Kişilerin (Rekreasyonistlerin) Örtük Liderlik Algıları. Anatolia: Turizm Araştırmaları Dergisi, 28(2), 227-243. https://doi.org/10.17123/atad.362528

Mumcu, H., \& Alay, O. S. (2018). Outdoor and indoor sports that require skill executive branches of the personality types of athletes. International journal of recreation and sport science, 2(1), 19-29. Retrieved from http://dergipark.gov.tr/ijrss/issue/41363/457042

Öksüz, Y., Ayvalı, M., Coşkun, K., Baba, M., \& İnci, A. (2011). Algılanan sosyal destekle akılcı olmayan 
davranışlar ilişkisi. International Journal of Social Science, 4(1), 119-136.

Peker, A., \& Eroğlu, Y. (2015). Ergenlerde algılanan sosyal destek ve siber zorbalığa eğilim arasındaki ilişkiler: Arkadaştan ve öğretmenden algılanan sosyal desteğin aracı rolü. Turkish Studies, 10(3), 759-778. https://doi.org/10.7827/TurkishStudies.7693

Sarol, H. (2017). Examination of the constraints and facilitators to physical activity participation of individuals. Journal of Human Sciences, 14(4), 4354-4364. https://doi.org/10.14687/jhs.v14i4.5121

Soyer, F., Yıldız, N. O., Demirel, D. H., Serdar, E., Demirel, M., Ayhan, C., \& Demirhan, O. (2017). The investigation of the relationship between the factors that prevent university students from attending to the recreational activities and the life satisfaction of the participants. Journal of Human Sciences, 14(2), 2035-2046. https://doi.org/10.14687/jhs.v14i2.4647

Stokes, J. P., \& Wilson, D. G. (1984). The inventory of socially supportive behaviors: Dimensionality, prediction, and gender differences. American Journal of Community Psychology, 12(1), 53-69. https://doi.org/10.1007/BF00896928

Terzi, S. (2008). Üniversite öğrencilerinin psikolojik dayanıklılıkları ve algıladıkları sosyal destek arasındaki ilişki. Türk Psikolojik Danışma ve Rehberlik Dergisi, III(29), 1-11.

Thapa, B., Confer, J. J., \& Mendelsohn, J. (2004). Trip motivations among water-based recreationists. In Paper presentation at the 2nd International Conference on Monitoring and Management of Visitor Flows in Recreational and Protected Areas. Rovaniemi, Finland, 208-212.

Turgut, Ö., \& Çapan, B. E. (2017). Ergen Psikolojik Sağlamlık Düzeyinin Yordayıcıları: Algılanan Sosyal Destek ve Okul Bağllı̆ı̆ı. Mehmet Akif Ersoy Üniversitesi Ĕgitim Fakültesi Dergisi, 44, 162-183. https://doi.org/10.21764/maeuefd.309934

Twenge, J. M., Campbell, S. M., Hoffman, B. J., \& Lance, C. E. (2010). Generational differences in work values: Leisure and extrinsic values increasing, social and intrinsic values decreasing. Journal of management, 36(5), 1117-1142. https://doi.org/10.1177/0149206309352246

Uygur, S. S. (2018). Yaşam doyumunun yordanmasında kendini açma ve sosyal desteğin rolü. Ulusal Eğitim Akademisi Dergisi (UEAD), 2(1), 16-33.

Uzun, M., İmamoğlu, O., Yamaner, F., Deryahanoğlu, G., \& Yamaner, G. (2017). Examination of the factors which prevent to participate the recreative activities: Example of girls high school Rekreatif etkinliklere katılımı engelleyen faktörlerin incelenmesi: Kız lisesi örneği. Journal of Human Sciences, 14(1), 950-962. https://doi.org/10.14687/jhs.v14i1.4174

Yardimci, F. \& Basbakkal, Z. (2010). Çocuk-ergen sosyal destek olçegi'nin turkiye'deki geçerlik ve guvenirlik çalismasi. Anadolu Hemsirelik ve Saglik Bilimleri Dergisi, 12, 41-50. Retrieved from http://dergipark.gov.tr/ataunihem/issue/2645/34026

Yıldırım, İ. (2004). Algılanan sosyal destek ölçeğinin revizyonu. Eğitim Araştırmaları-Eurasian Journal of Educational Research, 17, 221-236.

Yıldırım, İ. (2016). Akademik başarı düzeyleri farklı olan lise öğrencilerinin bazı değişkenlere göre sosyal destek düzeyleri. Türk Psikolojik Danışma ve Rehberlik Dergisi, 2(10).

Zhang, J., Brackbill, D., Yang, S., Becker, J., Herbert, N., \& Centola, D. (2016). Support or competition? How online social networks increase physical activity: A randomized controlled trial. Preventive medicine reports, 4, 453-458. https://doi.org/10.1016/j.pmedr.2016.08.008

\section{Copyrights}

Copyright for this article is retained by the author(s), with first publication rights granted to the journal.

This is an open-access article distributed under the terms and conditions of the Creative Commons Attribution license (http://creativecommons.org/licenses/by/4.0/). 